\title{
THE ANALYSIS OF STUDENTS' BARRIERS IN TRANSLATING THE DAILY INDONESIAN-ENGLISH EXPRESSION AT MA AS'ADIYAH PUTRI SENGKANG
}

\author{
Agustiani Khaeruddin \\ Muhammad Yaumi \\ English Education Department of UIN Alauddin Makassar \\ Agkh07@gmail.com
}

\begin{abstract}
This research was aimed to identify the second grade students of MA As'adiyah Sengkang's barriers in translating Indonesian-English questions of daily expression, factors affecting the barriers, and strategies to solve them. The data were analyzed by using the qualitative descriptive method. The instruments used were Forum Group Discussion (FGD), interview, and observation. The research informants were the second grade students of Ilmu Agama Islam (LAI) department at MA As'adiyah Putri Sengkang. The result of the research showed that some barriers that the students encountered were barriers in word ordering, grammar, the use of pronoun, the use of idiom, and lack of vocabulary. The barriers occurred because of some factors affecting, such as limited learning media, lack of English book references, limited English learning (only at school), lack of interest in both the English material and the teacher's teaching method, and the differences of students' ability in understanding English learning. Some strategies that the students did in solving the barriers were using a dictionary, using google translate, learning grammar from a book, asking the teacher or asking the other friends, learning English from the movies and songs, accessing Internet to learn in the Internet stall, and taking a course.
\end{abstract}

Keywords: Students' Barriers, Translating, the Daily Indonesian-English Expression

\section{A. INTRODUCTION}

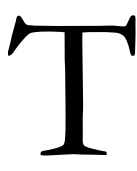

here are some barriers that translators especially language learners or students can encounter in translating, in this case, both directly and indirectly. In some sources, some barriers written are the barriers occuring directly. One of the example was quoted by Dulay that is written in Asik's book. He said that one of the serious barriers is that language learners are unable to transfer the equivalent meaning from the source language into the target language. In this case, the meaning which is not equivalent means absence of an item that must appear in a well-formed utterance, presence of an item which must not appear in a well-formed utterance, use of the wrong form of the morpheme or structure, or incorrect placement of a morpheme or group of morpheme in an utterance (Nur asik, 2012:17-20).

The barrier happens because of students' limited knowledge in both the source language and the target language. It also happens because the translation is not one of four English skills that the English teacher usually pay attention more of. Whereas, the translation 
is the most complex thing because students will need it in the four English skills such as writing, reading, speaking, and listening to make them more understandable.

From the previous statement, the researcher observed that the barriers that the previous researchers found were the barriers occuring in translating directly. There was still no barrier that can occur in translating indirectly. Therefore, the researcher was interested to conduct a research which analyzed students' barriers in translating both directly and indirectly.

By those considerations, the researcher framed her interest to conduct a research analyzing barriers that the students encounter in translation, especially in translating Indonesian question of daily expression into English. By finding out students' barriers in formulating English question, the possible teaching strategy as one of the important points in learning and teaching process could be identified and anticipated properly. Here did the researcher limit the topic to daily expression because translation learning could be started from the basic which was easy to understand by students. As the subject of this research also was the second grade students so the topic could be appropriate with them.

\section{B. LITERATURE REVIEW}

Several Studies had been conducted in order to identify some barriers in translating. First, Suhud who did a research about the students' ability in translating English paragraph through jig-saw learning strategy at MA Babussalam DDI Kassi Jeneponto, concluded that the result of the students' tests had achieved "fairly-good" level. However, the problem that students faced was less understanding in the content material before they translated. (Ahmad Ari Suhud, 2010).

Second, Rahmawati who did a research about the students' ability in translating modal auxiliary at SMPN 2 Sendana Kabupaten Majene, concluded that the mean score achieved by students through the test was classified as "very good". However the students still had problem in differentiating the functions of modal auxiliaries in sentence (Rahmawati, 2010, 40).

Based on the result of the studies, it can be concluded that there are some barriers in translating. However, the researcher was interested to get more common data that some researchers did not outline in their studies, in this case, some barriers occur both directly and indirectly.

\section{Translation}

Nida and Taber defined that translation consists of reproducing one language to the closest natural equivalent of the first language message, both in term of meaning and in term of style (Raena, 2010:9). The most important aspect in translating is the language itself, because it cannot be separated from translation (Douglas Robinson, 2005:240). The language to be translated is called the source language (SL), whereas the language to be translated into is 
called the target language (TL). In addition, most experts of translation have the same opinion that translator must have knowledge so that they can translate compatibly (M.R. Nababan, 2008:11). In this case, the translator needs to have good knowledge of both the source and the target language.

\section{Barriers in Translating}

Shankar defined barriers or obstacles as the means which check the free flow of communication that may be general or technical, and there are also some reasons why barriers can be generated (Dhruv Shankar, 2014:273). Every book is different and presents its own barriers in translating (Gill Paul,2009:41). According to Ghazala, some barriers that can occur in translating are phonological, lexical, grammatical, and stylistic barriers (Amina, 2010:4-6)

\section{Phonological Barriers}

These barriers are concerned with sounds. The barriers occur when the translator ignores how to transmit a particular sound, keeping the same meaning, into an appropriate equivalent in the target language.

\section{Lexical barriers}

These barriers are due to the misunderstanding or the total ignorance of the word's meaning. Lexical barriers which may be encountered when translating can be classified as literal meaning, synonyms, polysemy and monosemy, collocation, idioms, proverbs, metaphors, technical terms, proper names, titles, political establishments, geographical terms and acronyms.

\section{Grammatical Barriers}

These barriers are very common to occur in translating. One of many factors is caused by difference structure of both source language and target language.

\section{Stylistic Barriers}

These barriers are concerned with style, as it is a part of meaning, and its effect on words and grammar. The degree of formality and informality is a problem in translation since it affects strongly the meaning.

\section{RESEARCH METHOD}

This research used descriptive qualitative research. Descriptive means that the researcher needs to collect the data and describe what happens in the field. The data that has been collected is classified based on the kinds, characteristics, or the condition. Beside collecting data, qualitative research can also find new ideas and criticisms of the process that has been done, and it can become enrichment and improvement in the learning process. (Suharsimi Arikunto, 2013:3). 
The research participants that the researcher chose were the religion class of the second grade students of MA As'adiyah Putri Sengkang. The researcher chose the class because she knew that it focused on religion subjects too much; whereas the general subject, especially English subject sometimes was ignored.

In obtaining data, the researcher used three types of instrument, namely Focus Group Discussion (FGD), interview, and observation.

First, Focus Group Discussion (FGD) is defined as "a small gathering of individuals who have a common interest or characteristic assembled by the researcher who uses the group and its interaction as a way to gain in depth information about a particular topic" (Kark and Williams, 2013). The focus group is carefully designed to obtain perceptions, feelings, and experiences based on defined area of interest from limited number of people. The focus group are generally composed of six to twelve people and groups greater than twelve tend to break apart into various vactions while groups less than six generally not ideal enough to provide the required synergy (Anderson, 2013). Here did the researcher choose twelve participants randomly. In addition, the topic that was discussed included the common barriers that the students usually face, what causes the barriers, and what students have done to overcome it.

Second, the kind of interview that the researcher used was semi-structured interview. It means that the researcher brought a reference which contained a broad outline about some things that she wanted to ask. The participants that the researcher interviewed was about eight participants that were chosen based on the participants of FGD that had given clear information based on the researcher's need. This instrument aimed to know the common barriers, what caused the barriers, and what students had done to overcome them. In this case, the researcher asked the information directly and deeply.

Third, the observation that the researcher used was to gather more data in order to enrich the collected data. There were two kinds of observation that the researcher used namely classroom observation and document review. Classroom observation means that the researcher observed the situation in the class during the process of teaching translation. Whereas, document review means that the researcher observed the result of students' tasks given by the English teacher after giving the material, in this case, translation task. Document review aimed to identify whether the students' translation task was appropriate with the result of students' FGD and interview or not.

In collecting data, the researcher obeyed certain procedures as follows: FGD (Focus Group Discussion)

1. The researcher prepared the tools in collecting data, namely interview guide, tape recorder, and notebook.

2. The researcher chose some students randomly to be participants in FGD. The students chosen were twelve students. 
3. The researcher asked questions to be discussed in FGD, and students answered.

4. When the FGD run, the researcher recorded all the words that students say by video.

5. After FGD was done, the researcher chose eight students that gave more information, based on the researcher's observation, to be interviewed.

\section{Interview}

1. The researcher explained the procedures in interview that would be held.

2. The researcher called students chosen one by one to be interviewed.

3. When the researcher interviewed students, she also recorded the conversation between them and wrote some information that she got.

\section{Observation}

1) The researcher did observation when the teacher was teaching in the class.

2) The researcher did observation by noticing some items in observation attachment.

The researcher also observed the students' answer sheets in doing translation task.

In analyzing data, the researcher used qualitative analysis. Here did the researcher used Miles \& Huberman Model in analyzing data. There are three activities in analyzing data, namely data reduction, data display, and conclusion drawing/ verification Miles and Huberman, 2010:12).

The first step is data reduction. The data that the researcher collected in the field was in the complex and many forms. Therefore, the researcher had to concise the data which she needed to bring it to the next step in analyzing data and throw out the data that was not needed. In this case, the data needed was the data with finding values that would help the researcher in making conclusion based on the research method that she used.

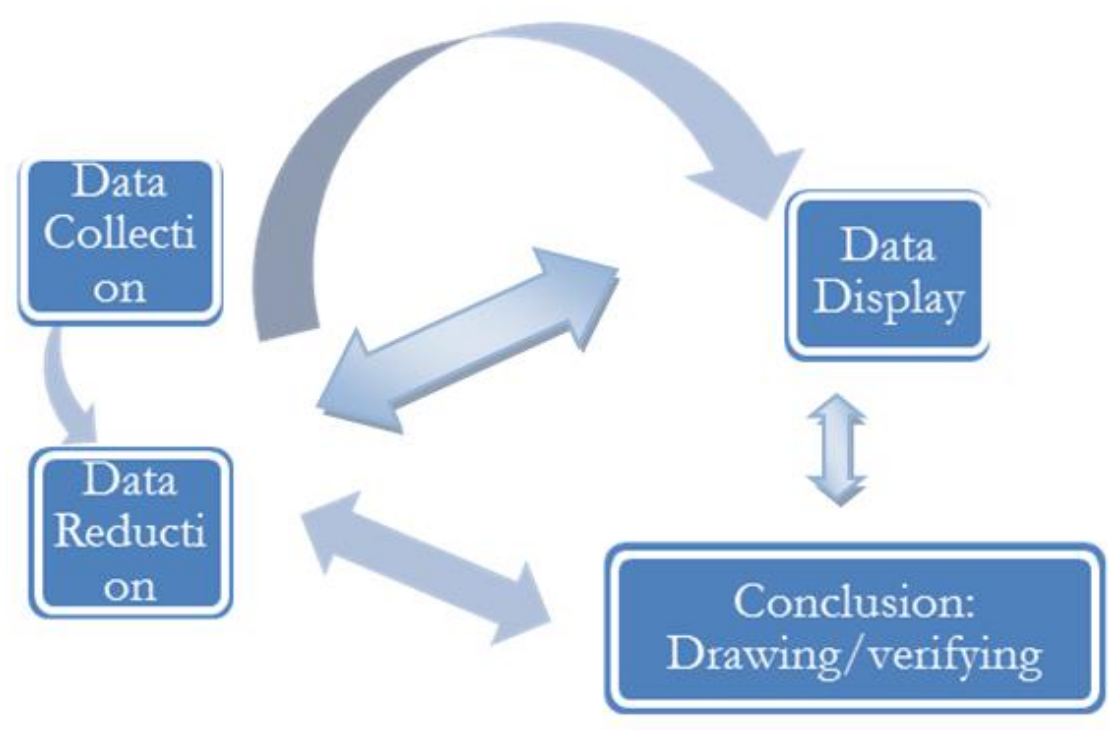

(Miles and Huberman, 2010:12) 
The second one is data display. Displaying data is presenting data into the pattern. In qualitative research, the data can be displayed by using a brief description, chart, the relationship among the categories, and so on. However Miles and Huberman emphasized that the way in displaying data that is frequently used is narrative text (Sugiyono,2012). However, beside narrative text, the researcher also uses tables.

The third one is conclusion drawing/ verification. Conclusion drawing is describing all of the data that has been analyzed. The conclusion is a new finding that can be a hypothesis, even a theory if it is supported by some data widely.

In conducting research, there were some principles associated with ethical conduct that the researcher needed to obey, namely do not harm, privacy and anonymity, confidentiality, informed consent, rapport and friendship, intrusiveness, and inappropriate bebavior (Internet, Retrieved 19 March 2016).

1. Do not Harm: The researcher did not have to involve the research participants in any situation in which they might be harmed.

2. Privacy and Anonymity: The general rule here was the researcher might not state in her research finding about what the participant did not want to.

3. Confidentiality: The researcher treated the research by confidential manner, and it was the researcher's responsibility.

4. Informed Consent: The research participants involved in the research could choose whether or not to participate. In this case, the researcher could not force them to join the research.

5. Rapport and Friendship: The researcher could make rapport among them, but the researcher could not make friendship because it involved the researcher's emotion deeply.

6. Intrusiveness: The researcher could not disturb the research participants' time, their space, and their personal lives.

7. Inappropriate Behavior: Not only the researcher, but also the research participants had to avoid inappropriate behavior in conducting research because all we had to have was respect one another. 


\section{FINDINGS AND DISCUSSION}

Research Findings through Forum Group Discussion (FGD)

Some barriers that the students described have been outlined into the following table:

Table 1. Data Display of Forum Group Discussion (FGD)

\begin{tabular}{|c|c|c|}
\hline \multicolumn{3}{|c|}{ The Researcher's Questions } \\
\hline $\begin{array}{c}\text { Students' Barriers in } \\
\text { translation/ general } \\
\text { English }\end{array}$ & The Causes of The Barriers & $\begin{array}{l}\text { The Strategies to } \\
\text { Solve the Barriers }\end{array}$ \\
\hline $\begin{array}{l}\text { - Word Order } \\
\text { - Idioms } \\
\text { - Lack of vocabulary } \\
\text { - Lack of confidence }\end{array}$ & $\begin{array}{l}\text { - Seldom opening the books } \\
\text { - Lack of mastery in grammar } \\
\text { - Not interested in English } \\
\text { - Lack of interest in the teacher's } \\
\text { teaching method } \\
\text { - The students' perspective towards } \\
\text { how difficult English is } \\
\text { - Seldom practicing daily English } \\
\text { expression } \\
\text { - Consideration of Arabic learning } \\
\text { more often than English learning } \\
\text { itself } \\
\text { - No electronic tools, such as } \\
\text { handphone and laptop, to access } \\
\text { Internet }\end{array}$ & $\begin{array}{l}\text { - Self - awareness in } \\
\text { learning } \\
\text { - Taking a course } \\
\text { - Accessing Internet in } \\
\text { Internet stall } \\
\text { - Asking smarter friends }\end{array}$ \\
\hline
\end{tabular}

Research Findings through Semi-Structured Interview

Here did the researcher display the students' answers in interview section that were supported by some proofs based on the students' answers in translation task, into the following table.

Table 2. Data Display of Semi - Structure Interview

\begin{tabular}{|c|c|c|c|c|}
\hline No. & $\begin{array}{l}\text { Research } \\
\text { Participant }\end{array}$ & Barriers Faced & $\begin{array}{l}\text { The causes of } \\
\text { Those Barriers }\end{array}$ & $\begin{array}{c}\text { Strategies to } \\
\text { Those Solve } \\
\text { Barriers }\end{array}$ \\
\hline 1. & Student 1 & $\begin{array}{l}\text { - Word order } \\
\text { E.g: } \\
\text { "Who is your name father?" } \\
\text { (NSR) } \\
\text { [What is your father's } \\
\text { name?] } \\
\text { - Grammar } \\
\text { E.g: } \\
\text { "When and where your } \\
\text { born?" (NSR) } \\
\text { [When and where were you } \\
\text { born?] } \\
\text { - Vocabulary }\end{array}$ & - No answer & $\begin{array}{l}\text { - learning from } \\
\text { the books }\end{array}$ \\
\hline
\end{tabular}




\begin{tabular}{|c|c|c|c|c|}
\hline & & $\begin{array}{l}\text { E.g: } \\
\text { "Where your grandfather } \\
\text { and grandmother leave?" } \\
\text { (NSR) } \\
\text { [Where do your grandfather } \\
\text { and grandmother live?] }\end{array}$ & & \\
\hline 2. & Student 2 & $\begin{array}{l}\text { Vocabulary (many } \\
\text { synonyms, idioms) } \\
\text { E.g: } \\
\text { "When and where your } \\
\text { exerior?"( NA) } \\
\text { [When and where were you } \\
\text { born?] }\end{array}$ & $\begin{array}{l}\text { - Lack of } \\
\text { references in } \\
\text { learning }\end{array}$ & $\begin{array}{l}\text { - Loving the } \\
\text { subjects } \\
\text { - Paying } \\
\text { attention of } \\
\text { the teacher's } \\
\text { explanation } \\
\text { - Learning step } \\
\text { by step } \\
\text { - Taking a } \\
\text { course }\end{array}$ \\
\hline 3. & Student 3 & $\begin{array}{l}\text { - Many synonyms of a word } \\
\text { E.g: } \\
\text { "How many your age?" } \\
\text { [How old are you?] } \\
\text { - Where to use a word } \\
\text { E.g: What is your } \\
\text { ambition?" } \\
\text { - Grammar } \\
\text { E.g: } \\
\text { "How many your brother } \\
\text { and your sister?" } \\
\text { [How many brothers and } \\
\text { sisters do you have?] }\end{array}$ & $\begin{array}{l}\text { - Limited } \\
\text { media in } \\
\text { learning (no } \\
\text { laptop or } \\
\text { another } \\
\text { electronic } \\
\text { tool) }\end{array}$ & $\begin{array}{l}\text { - Asking the } \\
\text { teacher } \\
\text { - Using a } \\
\text { dictionary } \\
\text { - Learning from } \\
\text { friends }\end{array}$ \\
\hline 4. & Student 4 & $\begin{array}{l}\text { - Grammar (not understand } \\
\text { how to use past tense) } \\
\text { E.g.: } \\
\text { "When and where you } \\
\text { borne?" } \\
\text { [When and where were you } \\
\text { born?] } \\
\text { - Sentence Structure form } \\
\text { E.g.: } \\
\text { "What is you always do?" } \\
\text { [Do you always do it?] }\end{array}$ & $\begin{array}{l}\text { - Lack of } \\
\text { learning }\end{array}$ & $\begin{array}{l}\text { - Learning from } \\
\text { movie } \\
\text { - Not learning } \\
\text { from the } \\
\text { grammar first }\end{array}$ \\
\hline 5. & Student 5 & $\begin{array}{l}\text { How to choose an } \\
\text { appropriate word in } \\
\text { dictionary } \\
\text { E.g.: } \\
\text { "When and where you } \\
\text { extranal?" }\end{array}$ & $\begin{array}{l}\text { - English is a } \\
\text { difficult } \\
\text { subject to } \\
\text { learn }\end{array}$ & $\begin{array}{l}\text { - Learning with } \\
\text { friends }\end{array}$ \\
\hline
\end{tabular}




\begin{tabular}{|c|c|c|c|c|}
\hline & & $\begin{array}{l}\text { [When and where were you } \\
\text { born?] } \\
\text { - Lack of vocabulary } \\
\text { E. g.: } \\
\text { "What is your sudy } \\
\text { faforite?" } \\
\text { [What is your favorite } \\
\text { subject?] } \\
\text { - No dictionary } \\
\text { - Using Google Translate in } \\
\text { translating } \\
\text { - Grammar } \\
\text { E.g.: } \\
\text { "Why you like?" } \\
\text { [Why do you like it?] }\end{array}$ & & \\
\hline 6. & Student 6 & $\begin{array}{l}\text { - Lack of vocabulary } \\
\text { E.g.: } \\
\text { "When and where your } \\
\text { livit?" } \\
\text { [When and where were you } \\
\text { born?] } \\
\text { - Grammar } \\
\text { E.g.: } \\
\text { "What job your father?" } \\
\text { [What is your father's job?] }\end{array}$ & $\begin{array}{l}\text { - Not } \\
\text { interested in } \\
\text { difficult } \\
\text { material } \\
\text { - Lazy to read } \\
\text { English } \\
\text { books } \\
\text { - Cannot learn } \\
\text { autodidacticly }\end{array}$ & $\begin{array}{l}\text { - Learning from } \\
\text { English songs } \\
\text { - Asking friends }\end{array}$ \\
\hline 7. & Student 7 & $\begin{array}{l}\text { - The structure of sentences } \\
\text { E.g.: } \\
\text { "Why you to wish } \\
\text { become?" } \\
\text { [Why do you want to be a } \\
\text {..?] } \\
\text { - Word order } \\
\text { E.g.: } \\
\text { "Where grandfather and } \\
\text { grandmother you live?" } \\
\text { [Where do your grandfather } \\
\text { and grandmother live?] } \\
\text { - Not interested in the } \\
\text { teacher's method, } \\
\text { sometimes }\end{array}$ & $\begin{array}{l}\text { - Not } \\
\text { understand in } \\
\text { listening to } \\
\text { material from } \\
\text { the teacher }\end{array}$ & $\begin{array}{l}\text { - Repeat } \\
\text { learning }\end{array}$ \\
\hline 8. & Student 8 & $\begin{array}{l}\text { - Word order } \\
\text { E.g.: } \\
\text { "What you'r mother is } \\
\text { job?" } \\
\text { [What is your mother's } \\
\text { job?] } \\
\text { - English structure } \\
\text { E.g.: }\end{array}$ & $\begin{array}{l}\text { - Seldom } \\
\text { reading } \\
\text { English } \\
\text { books }\end{array}$ & $\begin{array}{l}\text { - Asking } \\
\text { smarter } \\
\text { friends } \\
\text { - Practicing } \\
\text { English } \\
\text { - Watching } \\
\text { English movie, }\end{array}$ \\
\hline
\end{tabular}




\begin{tabular}{|c|c|c|c|}
\hline & & $\begin{array}{l}\text { "What you like is?" } \\
\text { [Why do you like it?] } \\
\text { - Vocabulary } \\
\text { - Word option } \\
\text { E.g.: } \\
\text { "What you'r sentiment?" } \\
\text { [What is vour idea?] }\end{array}$ & $\begin{array}{l}\text { but focusing } \\
\text { on its subtitle }\end{array}$ \\
\hline
\end{tabular}

\section{Research Findings through Observation}

Based on the researcher's explanation, there were two kinds of observation that the researcher used, namely classroom observation and document review.

a. Research Findings through Classroom Observation

Classroom observation was done to adjust the data discovered from Forum Group Discussion (FGD) and interview. The data found from classroom observation was described in the following table.

Table 3. Data Display of Classroom Observation

\begin{tabular}{|c|c|c|}
\hline No. & Objects of Observation & Researcher's Interpretation \\
\hline 1. & Classroom setting & $\begin{array}{l}\text { "Classroom used by them was language laboratory } \\
\text { room. However, some learning media that could help } \\
\text { the learning process was not used. Besides, the room } \\
\text { also has been used by them as their own class, so the } \\
\text { room was not only used in English subject, but also } \\
\text { used in the other subjects." }\end{array}$ \\
\hline 2. & $\begin{array}{l}\text { Opening and Closing } \\
\text { learning }\end{array}$ & $\begin{array}{l}\text { "The teacher opened the class by some opening } \\
\text { words and checked the attendance list. The students } \\
\text { payed attention of the teacher well. It was proved by } \\
\text { the students' silence when the teacher spoke. } \\
\text { Whereas, the teacher closed the class by doing } \\
\text { evaluation and giving the students translation task." }\end{array}$ \\
\hline 3. & Teacher's teaching method & "The teacher used Grammar Translation Method." \\
\hline 4. & Learning strategy & $\begin{array}{l}\text { "The students were taught by using mother language, } \\
\text { but sometimes combined with English. In teaching, } \\
\text { the teacher emphasized grammar in her } \\
\text { explanation." }\end{array}$ \\
\hline 5. & Students' involvement & $\begin{array}{l}\text { "Some students were active to respond the teacher's } \\
\text { questions. However, some of them also just listened } \\
\text { to the teacher without responding." }\end{array}$ \\
\hline 6. & $\begin{array}{lll}\text { Students' } & \text { attitude in } \\
\text { translating } & & \end{array}$ & $\begin{array}{l}\text { "Some students looked enthusiastic in translating the } \\
\text { sentence given by the teacher, but the answers given } \\
\text { was not exactly correct yet." }\end{array}$ \\
\hline 7. & $\begin{array}{l}\text { Given translation task by } \\
\text { the teacher }\end{array}$ & $\begin{array}{l}\text { "The teacher gave the students translation task that } \\
\text { consisted of } 15 \text { items. The translation task contained }\end{array}$ \\
\hline
\end{tabular}




\begin{tabular}{|l|l|l|}
\hline & $\begin{array}{l}\text { translation Indonesian - English question of self } \\
\text { introduction.” }\end{array}$ \\
\hline
\end{tabular}

b. Research Findings through Document Review

Document review that the researcher means here is the data observed from the students' translation task, in this case, translation task. Here does the researcher described it in the following table.

Table 4. Data Display of Document Review

\begin{tabular}{|c|l|}
\hline No. & \multicolumn{1}{|c|}{ Barriers Encountered by Students } \\
\hline 1. & Most of students encountered problems in ordering words. \\
\hline 2. & Most of students encountered problems in grammar. \\
\hline 3. & Most of students encountered errors in choosing an appropriate word. \\
\hline 4. & Most of students encountered errors because of lack of vocabulary. \\
\hline 5. & Some students still got difficulties in using an appropriate pronoun. \\
\hline
\end{tabular}

\section{E. CONCLUSION}

The result of this study showed that the barriers that the second-grade students of MA As'adiyah Putri Sengkang encountered were barriers in word ordering, grammar, using pronoun, using idiom, and lack of vocabulary. In addition, most of students translated a sentence by using strategy translating word by word.

The causes of the barriers were limited learning media (especially, electronic tools, such as hand phone and laptop), lack of English book references, limited English learning (only at school), lack of interest in both the English material and the teacher's teaching method, and the differences of students' ability in understanding English learning.

Some strategies that the second-grade students of MA As'adiyah Putri Sengkang did in solving the barriers were using a dictionary, using google translate, learning grammar from a book, asking the teacher or asking the other friends, learning English from the movies and songs, accessing Internet to learn in the Internet stall, and taking a course.

\section{Recommendation}

Based on the conclusions, the researcher suggests that the headmaster can support the students' efforts in learning, such as giving them permission to bring laptop to access Internet. As we know, there is an Internet network or $W i-F i$ which is provided in that school. The students also have authorities in using it. It will be better also if the teacher asks the students' perspective towards English learning, and ask about the students' need. It is because the students have different barriers in learning, especially in English translation learning.Then, the researcher also suggests that the students should search the other references in learning. They are also recommended to ask their English teacher what they want in learning. By doing so, they can improve their comprehension towards translation learning itself. 
Finally, for further researcher, the researcher suggests him/ her to do classroom action research to develop this research and to help the students' achievement in translation class.

\section{REFERENCES}

Amina, MA. "Lexical Translation Problems": The Problem of Translating Phrasal Verbs. Master Degree Thesis. Constantine: Mentouri University, 2011.

Arikunto, Suharsimi. Prosedur Penelitian. Jakarta: Rineka Cipta, 2013.

Asik, Nur. Error Analysis in Making English Questions. Makassar: Alauddin University Press, 2006.

Miles, B. Matthew \& Michael Huberman, Qualitative Data Analysis, London: Sage Publication.

Nababan, R. "Kompetensi Penerjemahan dan Dampaknya pada Kualitas Terjemahan." Professor Inauguration Speech, Surakarta: Universitas Sebelas Maret, 2008.

Paul, Gill. ed. Translation in Practice. London: Dalkey Archive Press, 2009.

Raena. Analyzing the Difficulties Faced by The Second Year Students of SMA Mubammadiyah 6 Makassar in Translating English Conjunctions. Degree Thesis. UIN Alauddin Makassar, 2010.

Rahmawati. The Ability of the Second Year Students in Translating Modal Auxiliary in SMPN 2 Sendana Kabupaten Majene. Degree Thesis. UIN Alauddin Makassar, 2010.

Robinson, Douglas. Menjadi Penerjemah Profesional. Yogyakarta: Pustaka Pelajar, 2005.

Shankar, Shankar. "Research Journal of English Language and Literature (RJELAL): Barriers and Obstacles of Techno - Lingual Communication". A Peer Reviewed International Journal 2, no. 3 (2014).

Satory, D \& A Komariah. Metodologi Penelitian Kualitatif. Bandung: ALFABETA, 2011.

Sugiyono. Metode Penelitian Kuantitatif Kualitatif dan R\&D. Bandung: ALFABETA, 2012.

Suhud. The Ability of the Second Year Students in Translating English Paragraph through Jigsaw Learning Strategy in MA Babussalam DDI Kassi Jeneponto. Degree Thesis. UIN Alauddin Makassar, 2010.

Tichapondwa, SM. "Preparing your Dissertation at a Distance": A Research Guide, Retrived from Vancouver :Virtual University For Small States of the Collon wealth. website: http: //www. sadc. int/ files/ 3713/ 7821/ 2867/ Dissertation_ PDF. pdf. (2013).

"Tradition and Influences": Ethical Issues in Qualitative Research, https: / $/$ www.google.co.id/url? sa $=\mathrm{t} \& \mathrm{rct}=\mathrm{j} \& \mathrm{q}=\& \mathrm{esrc}=\mathrm{s} \&$ source $=$ web\&cd $=1 \& \mathrm{cad}=\mathrm{r}$ ja\&uact $=8 \&$ ved $=0$ ahUKEwjos9aBh8zLAhXXxI4KHQx9Dc4QFggaMAA\&url $=\mathrm{htt}$ $\mathrm{p} \% 3 \mathrm{~A} \% 2 \mathrm{~F} \% 2 \mathrm{Fuk}$.sagepub.com $\% 2 \mathrm{Fsites} \% 2 \mathrm{Fdefault} \% 2 \mathrm{Ffiles} \% 2 \mathrm{Fupmbinaries} \% 2 \mathrm{~F} 2$ 7011_4.pdf\&usg=AFQjCNH6OgmEqkaszNBYvk1EcycZNkuqw\&sig2=jTyAD0pmdAkt_ROPP8AQA\&bvm=bv.117218890,d.c2E (March 19, 2016). 